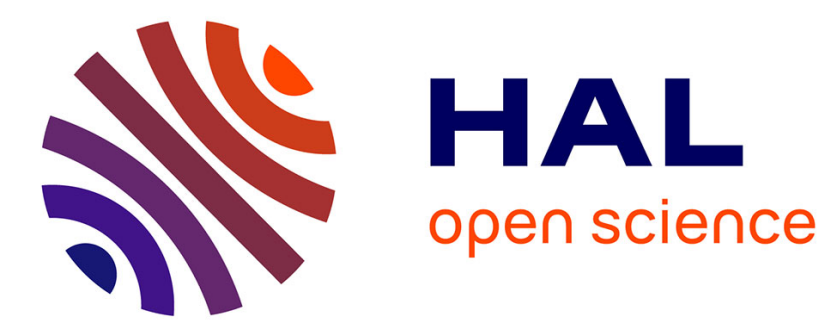

\title{
A day in the life of an oil bee: phenology, nesting, and foraging behavior
}

Irmgard Schäffler, Stefan Dötterl

\section{To cite this version:}

Irmgard Schäffler, Stefan Dötterl. A day in the life of an oil bee: phenology, nesting, and foraging behavior. Apidologie, 2011, 42 (3), pp.409-424. 10.1007/s13592-011-0010-3 . hal-01003522

\section{HAL Id: hal-01003522 \\ https://hal.science/hal-01003522}

Submitted on 1 Jan 2011

HAL is a multi-disciplinary open access archive for the deposit and dissemination of scientific research documents, whether they are published or not. The documents may come from teaching and research institutions in France or abroad, or from public or private research centers.
L'archive ouverte pluridisciplinaire HAL, est destinée au dépôt et à la diffusion de documents scientifiques de niveau recherche, publiés ou non, émanant des établissements d'enseignement et de recherche français ou étrangers, des laboratoires publics ou privés. 


\title{
A day in the life of an oil bee: phenology, nesting, and foraging behavior
}

\author{
Irmgard SCHÄFFLER ${ }^{1}$, Stefan DötTERL ${ }^{1,2}$ \\ ${ }^{1}$ Department of Plant Systematics, University of Bayreuth, 95440 Bayreuth, Germany
${ }^{2}$ Department of Plant Systematics, University of Bayreuth, Universitätsstr. 30, 95447 Bayreuth, Germany
}

Received 12 April 2010 - Revised 26 July 2010 - Accepted 30 July 2010

\begin{abstract}
Little is known about the bionomics of solitary, ground-nesting bees. We established a population of the oil bee, Macropis fulvipes, in a flight cage and recorded the emergence phenology, sex ratio, nesting behavior, and foraging behavior of individually marked bees. The population was protandrous and the sex ratio was balanced in three of the four observation years. The date of first emergence varied even though the sum of temperatures before emergence was similar across years. Adults of both sexes fed on the pollen of Lysimachia punctata host plants. Females additionally visited flowers to collect oil for the nest-cell lining, as well as oil and pollen for larval provisions. Duration of collecting trips, flower visits, and nest stays were influenced by the reward collected. Bees required 12 collecting trips and 460 visitations to flowers to complete a single cell. Therefore, to sustain a viable population of 50-500 individuals, 20,000-200,000 flowers are required. Our study shows that observations in a closed system can provide new insights into the bionomics of bees.
\end{abstract}

Macropis fulvipes / oil bee / sum of temperature / solitary bee / Lysimachia / host plant requirement / nesting behavior / provisioning behavior

\section{INTRODUCTION}

Pollination is a process that occurs in almost all terrestrial ecosystems, and which is responsible for the seed set of many plant species as well as the genetic diversity of plant populations. Currently, pollination systems are threatened in many ecosystems (Murray et al. 2009) by lack of sustainably managed pollinators (Kevan and Phillips 2001) as well as by changes in the land use, which may threaten some native pollinators (Kearns and Inouye 1997). The main animal pollinators of wild plants and crops are managed honey bees (Kevan 1999) and native bees (Batra 1995; Klein et al. 2007). However, managed (Cox-Foster et al. 2007) as well as

Corresponding author: S. Dötterl,

Stefan.Doetterl@uni-bayreuth.de

Manuscript editor: Marla Spivak unmanaged wild bee populations (SteffanDewenter et al. 2005; Biesmeijer et al. 2006; Murray et al. 2009) are subject to high rates of localized extinction. Understanding the biology of bees (e.g., host plant requirement, nesting biology, and phenology), especially of native wild bees, is important if we wish to protect and preserve these species, which would be one step towards ensuring pollination of wild and cultivated plants.

Pollinating bees typically use pollen and nectar as larval food. Quite a few bee species (360-370), however, use floral fatty oils together with or in lieu of nectar. 1,5001,800 plant species produce this oil in specific floral organs, called elaiophores (Vogel 1974; Simpson and Neff 1981; Neff and Simpson 2005; Renner and Schäfer 2010). Some of the specialized oil bees additionally use the oil in the process of nest construction to line the cell 
wall (Cane et al. 1983b; Vogel 1986; Jesus and Garófalo 2000; Alves-Dos-Santos et al. 2002; Aguiar and Garófalo 2004).

Oil producing flowers and oil collecting bees are most widespread in the Neotropics, but these systems also occur in the Palaeotropics, Holarctic, and Southern Africa (Cape) (Neff and Simpson 2005). Oil collecting bees of the Neotropics and South Africa typically collect pollen from a variety of non-oil plants, whereas oil bees of the Palaeotropics and Holarctic collect pollen exclusively from their oil hosts. The only oil flowers in the Holarctic are 75 Lysimachia species (Myrsinaceae), which are tightly associated with the Holarctic Macropis bees (Melittidae; Melittinae). These bees collect oil and pollen from Lysimachia as the only food for their larvae and additionally use the oil to line their brood cells (Vogel 1976, 1986; Cane et al. 1983a; Buchmann 1987). Lysimachia flowers do not produce nectar, and adult Macropis visit a variety of other plants for nectar (Vogel 1986).

Macropis fulvipes (Fabricius 1804) is a widespread oil bee in Europe (Michez and Patiny 2005). It is a univoltine, solitary, and gregarious ground nester (Malyshev 1929). For nesting, M. fulvipes prefers banks or sloping ground and builds its cells near the surface (depth about $2.5 \mathrm{~cm}$ ). The nests consist of a main tunnel with two or three lateral branches (each about 5 to $8 \mathrm{~cm}$ long) situated near the distal end of the main tube. Each branch has at most two cells situated end to end (Vogel 1986 and Celary 2004). Lysimachia punctata L. is an important host plant, and the interaction between M. fulvipes and L. punctata was studied in a pioneering study by Vogel (1986). He described the floral structure of Lysimachia and that of their elaiophores, analyzed the composition of the floral oil, and studied the morphological structures used by the bee to collect and transport the oil from Lysimachia to the nest. He also described the behavior of bees (in natural habitats) during harvesting of pollen and oil, and characterized the cell lining built with oil (see also, Cane et al. 1983a). Vogel (1986) also quantified the behavior of Macropis (e.g., number of flower visits and time needed for one collecting trip, number of collecting trips to build one cell), although he did not observe the bees during entire collecting trips or from the beginning to the end of cell provisioning. It was not possible to observe individual bees in the field at their nests and at host plant sites; therefore, several of these quantitative measurements - such as their floral requirements - are not conclusive. In Macropis, as in other specialized bees, the number of flowers needed to collect the reward for one offspring is especially important to know. Such data are necessary to determine the size of a plant population needed to sustain a viable bee population for conservation purposes. So far, however, the floral demand has been estimated only for a small number of bee species (Müller et al. 2006, and references therein).

We established a population of $M$. fulvipes in a flight cage and studied their emergence phenology, foraging and nesting behaviors, sex ratio, floral requirements (i.e., number of flowers needed) for constructing and provisioning one cell, and the weight of oil and pollen loads relative to the fresh weight of the bees. Our observations also revealed the factors that promote initiation of nesting behavior in Macropis.

\section{MATERIAL AND METHODS}

\subsection{Study site}

A population of $M$. fulvipes, nesting in the soil adhering to the bottom side of an uprooted beech stump, was caged in a greenhouse in the Ecological Botanical Garden (EBG) of the University of Bayreuth in spring 2006 (flight cage, 7.2 $\times 3.6 \times$ $2.2 \mathrm{~m}$; wood-framed mesh gauze; Dötterl and Schäffler 2007). The side windows $\left(2 \times 15 \mathrm{~m}^{2}\right)$ and the roof lights $\left(2 \times 20 \mathrm{~m}^{2}\right)$ of the greenhouse were opened to avoid excessive temperatures. We offered the bees, which eclosed from the beech stump, $L$. punctata as a pollen and oil source, and Geranium sanguineum L. and Origanum vulgare L. as nectar sources. Bees additionally were provided with a sugar solution $(30 \%$, a $1: 1$ mixture of glucose and 
fructose) that was added to the Geranium flowers or to an artificial feeder. Soil was arranged in a mound to offer additional nesting sites. To increase the population size of Macropis in the flight cage, free flying bees were caught in the EBG and introduced in the cage. Each bee that emerged from the stump nests or was introduced from outside the flight cage was marked with a plastic disc commonly used for marking honey bee queens (Opalith number plates, $1-99$, in five colors). Because M. fulvipes is smaller than a honey bee queen, each label was trimmed to fit its smaller thorax. Before tagging, each bee was cooled on ice for several minutes. A few minutes after releasing, the tagged bees behaved normally.

\subsection{Emergence phenology}

The emergence phenology of M. fulvipes was recorded in 2006, 2007, 2008, and 2009. Newly eclosed bees were regularly marked (every $1-3$ days) throughout the emergence periods. To test whether males and females emerged synchronously, the datasets of eclosed bees were compared separately for each year using a logistic model (StatSoft, Inc. 2004). The sex of the bees was coded as a dependent variable, and emergence day was used as a continuous predictor variable. In order to make the emergence dates of all 4 years comparable in one graphical representation, the days of emergence were aligned based on the first day of emergence. Total frequencies of emerged males and females each year were used to test whether the sex ratio was balanced (chi-square observed versus expected test, StatSoft, Inc. 2004).

\subsection{Calculation of temperature sums as a trigger for emergence}

Temperature sums are often used to forecast bud break or onset of flowering in plants (e.g., Galán et al. 2001). Because the phenology of Macropis had to be synchronized with the flowering period of the Lysimachia host plants, we applied temperature summing to forecast emergence of M. fulvipes. All daily average temperatures above an a priori defined temperature threshold and from an a priori defined date were cumulatively summed. To determine the temperature (measured at $2 \mathrm{~m}$ altitude) threshold and the date that most precisely forecasted the emergence of $M$. fulvipes, we first tested different thermal thresholds (from 0 to $15^{\circ} \mathrm{C}$, by steps of $1{ }^{\circ} \mathrm{C}$ ), and different dates (from 1st January to 1st April, by monthly steps) until the date where the first bee hatched. We performed these calculations for all 4 years (2006-2009) and compared the outcome among the years in order to calculate (depending on temperature threshold and date) the coefficient of variation $(\mathrm{CV}=\mathrm{SD} /$ mean). The $\mathrm{CV}$ was lowest when the temperature threshold was $4^{\circ} \mathrm{C}$, and when temperatures were summed beginning on 1st January (data not shown) indicating that these parameters were most appropriate to forecast the emergence of $M$. fulvipes (see Laaidi 2001, and Galán et al. 2001). We also determined, again separately for the four different years, the temperature sum of the 1-10 weeks prior to emergence, not to forecast, but to find the period before emergence that mostly influenced and triggered the emergence. By comparing the outcome among the years, we found that the $\mathrm{CV}$ was lowest when summing up the temperatures above $4^{\circ} \mathrm{C}$ during the last 5 weeks prior to eclosion (data not shown).

\subsection{Observation of bees provisioning cells}

In 2006, the behavior of female bees during provisioning of cells was investigated during good and comparable weather conditions. Preliminary observations revealed that Macropis bees visit their oil and pollen host Lysimachia for two purposes and in two distinct collecting trips: (1) to collect only floral oil and (2) to collect oil together with pollen during one flower visit (oil+pollen). To determine whether the two types of foraging trips occurred at different times of day, the number of females making each type of trip was recorded once per hour over a period of 11 days. Because of changing weather conditions during these days, however, it was not possible to monitor the number and type of foraging trips continuously from morning to evening. The number of replicates (days) ranged from one to 11. At a specific census, the percentage of bees that collected oil+pollen was calculated. We further used the total number of bees observed at a specific time of day that collected either oil or oil+ pollen (dependent categorical variable) to test whether time of day (continuous predictor) 
explained the reward collected by using a logistic model (Wald test; StatSoft, Inc. 2004).

As individually marked bees could be observed during the whole day, we further characterized the behavior of female bees during cell provisioning in detail. The following parameters were determined separately for oil and oil+pollen collecting trips: (a) duration of a collecting trip (time from leaving the nest until re-entering the nest with floral rewards), (b) number of flower visits per trip, (c) duration of a single flower visit, (d) time of a nest stay (the time from entering the nest after a trip until leaving the nest for another trip), and (e) number of trips required to complete one cell. Based on (b) and (e) we calculated the floral requirement. In cases where one parameter was recorded more than once for a specific individual, we calculated the mean and used this value for further calculations as parameters may be specific for each individual. Mann-Whitney $U$ tests (StatSoft, Inc. 2004) were used to compare the different parameters between oil and oil+pollen collecting trips.

To understand how floral oil was used by a bee after returning to the nest, a flexible endoscope (flexible fiber Uretero-Renoscope $\varnothing 3 \mathrm{~mm}$, type: 7,331.001 with a light cable $\varnothing 1.6 \mathrm{~mm}$, type: 8,061.16; Richard Wolf GmbH, Germany) was inserted into the nest to observe bee behavior.

To determine the mass of oil+pollen collected during one foraging trip, we weighed 10 females on an electronic balance (Sartorius 1409, Sartorius AG, Göttingen, Germany) both before (after leaving the nest) and after (before entering the nest) the trip. To facilitate weighing, bees were cooled on ice.

\section{RESULTS}

\subsection{Phenology}

In 2006, the emergence period began in the middle of June, whereas in the following years bees eclosed approximately 3 weeks earlier (Table I). The duration of the emergence period was 18 days in 2006, and between 30 and 40 days in the following years (Table I; Figure 1). The number of bees emerging in the different seasons varied from 32 to 65 for males and 42 to 70 for females. The population was protandrous in 2006, 2007, and 2009 (males left their nests earlier than females), whereas emergence of females and males was synchronous in 2008 (Figure 1). More females than males eclosed from the nesting sites in the flight cage in all 4 years, however, only in 2008 was this difference significant (Table I).

\subsection{Temperature sum}

Across years, the temperature sum from 1st January until hatching of the first bee individual was between 463 and $525 \mathrm{~K}$, and it varied between 299 and $307 \mathrm{~K}$ during the last 5 weeks before hatching (Table II).

\subsection{Eating pollen, nest initiation}

After emergence, both female and male bees visited Lysimachia flowers to feed on pollen. They facilitated this process by manipulating the anthers with their mandibles (Figure 2a, b).

Table I. Period of emergence of Macropis fulvipes males and females, number of emerged bees in the four observation years, and results of an observed versus expected chi-square test (test for a balanced sex ratio).

\begin{tabular}{|c|c|c|c|c|c|c|}
\hline \multirow[t]{2}{*}{ Year } & \multicolumn{2}{|c|}{ Period of emergence } & \multicolumn{2}{|c|}{ Number of emerged bees } & \multirow[t]{2}{*}{$\chi^{2}$} & \multirow[t]{2}{*}{$P$} \\
\hline & $\partial^{\lambda}$ & 우우 & $\hat{\partial} \hat{\sigma}$ & 우우 & & \\
\hline 2006 & 13-27 June & 17-30 June & 32 & 42 & 1.351 & 0.24 \\
\hline 2007 & 20 May-18 June & 21 May-25 June & 65 & 70 & 1.185 & 0.66 \\
\hline 2008 & 29 May-22 June & 27 May-25 June & 41 & 66 & 5.841 & $<0.015$ \\
\hline 2009 & 22 May-25 June & 23 May-30 June & 42 & 50 & 0.695 & 0.40 \\
\hline
\end{tabular}




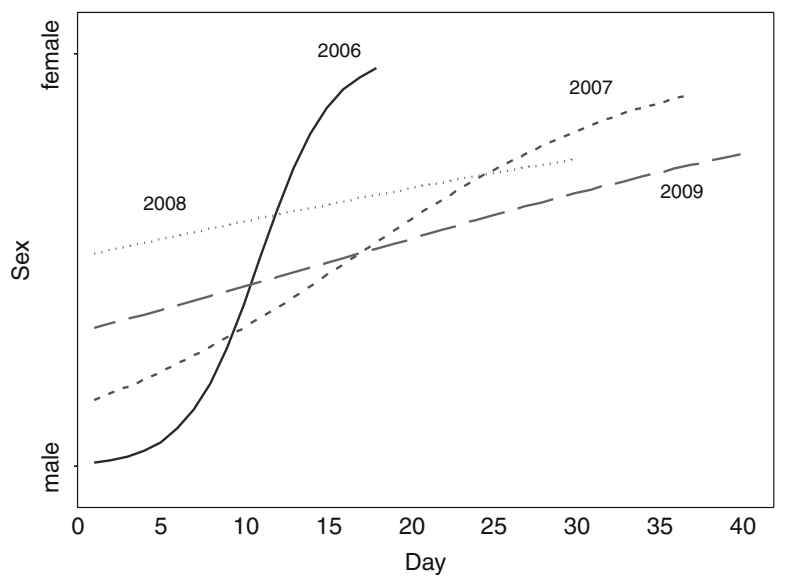

Figure 1. Fitted curves from logistic regressions on the sex of emerged bees in relation to the day of emergence (the day when the first bee emerged is given as day 1 in each year) in 2006-2009. In 2006, 2007, and 2009, the males emerged earlier than females (protandry); in 2008, both sexes emerged synchronously. Logistic regression - 2006: $\chi^{2}=39.57, P<0.01 ; 2007: \chi^{2}=17.81, P<0.01 ; 2008: \chi^{2}=1.65, P=0.19 ; 2009: \chi^{2}=4.98, P=0.02$.

Females did not show any collecting behavior for the subsequent few days. During this time, we observed them regularly resting (at night or during bad weather conditions) together with males in aggregations on Lysimachia or Geranium flowers (Figure 2c). Following pollen feeding, females often flew near potential nesting sites (rootstock and soil hill), hovered from time to time at specific sites, and finally selected a place for nesting. Most females built new nests, but some females used pre-existing nests left from the previous year(s).

\subsection{Collecting behavior}

Two to three days after eating pollen, females started to collect floral rewards for their larvae. The observation of the bees during foraging bouts revealed that they visit Lysimachia flowers to collect only oil, or to collect oil together with pollen. To collect oil, they touched the staminal tube as well as the base of the petals, where most of the oil glands are situated, with the tarsal pads of the middle and front legs. Thereby, oil was taken up by capillary action. During this collecting behavior, the abdomen was in line with the head and thorax, and typically did not contact the anthers. Observations of a bee inside the nest after oil collecting trips using a flexible endoscope demonstrated that she used the oil collected during the previous trip for the lining of the cell, and not as larval food. Inside the cell the female brushed the oil onto the cell wall with the hind legs (scopae, in which oil is transported), and thereby coated the cell wall with this oil.

Table II. Heat sum in K of the four observation years from the 1st January until emergence of the first bee individual, and during the last 5 weeks before emerging, respectively.

\begin{tabular}{lcccccc}
\hline & 2006 & 2007 & 2008 & 2009 & Mean \pm SD & CV \\
\hline 1st January until emergence & 508.8 & 524.7 & 470.4 & 462.8 & $491.7 \pm 26$ & 0.05 \\
5 weeks before emergence & 303.8 & 299.0 & 307.2 & 303.9 & $303.5 \pm 2.9$ & 0.01 \\
\hline
\end{tabular}



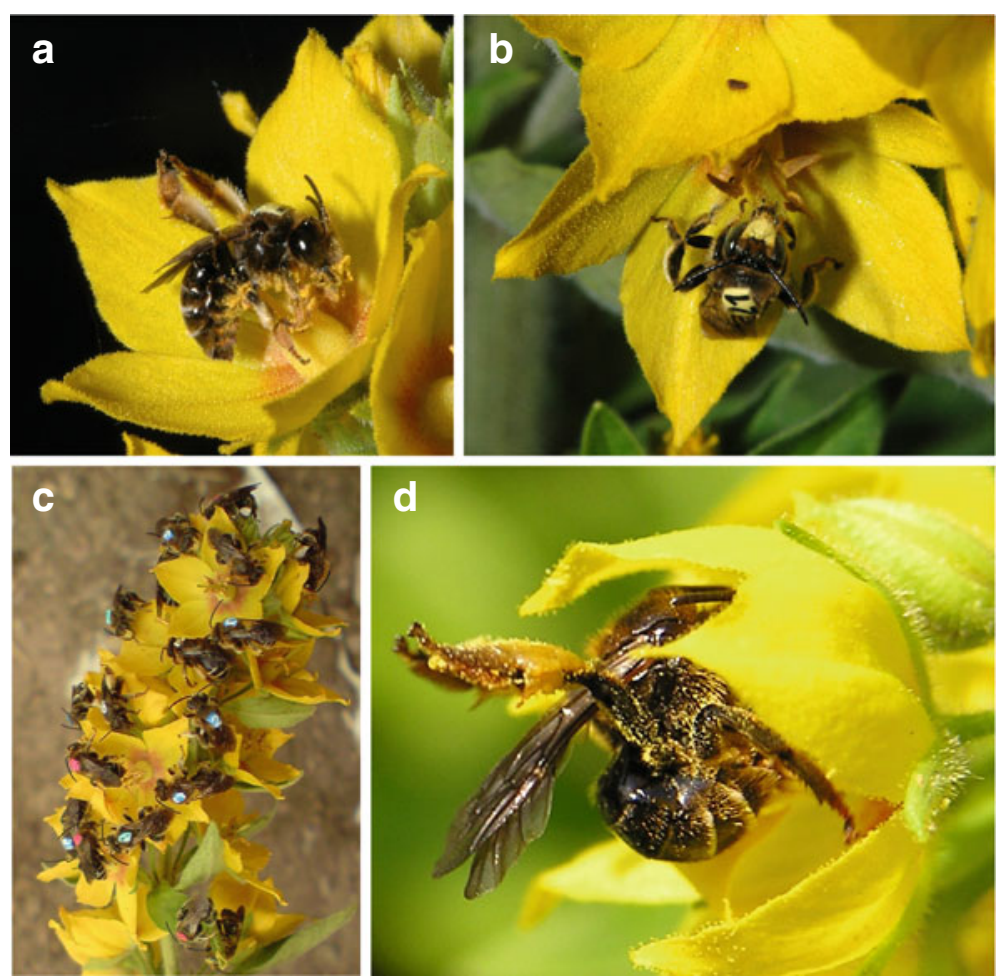

Figure 2. A newly emerged female (a) and male (b) of Macropis fulvipes feeding on pollen of Lysimachia punctata; individuals of both sexes resting on an inflorescence (c), and a female collecting oil+pollen (d). (d) was taken by Kathrin Milchreit.

Afterward, the bee licked the surface of the oilcontaining cell wall.

Bees collecting oil+ pollen handled the flowers quite differently from bees that collected only oil. To collect pollen, females pressed the ventral side of the abdomen (by bending) against the anthers (Figure 2d). Pollen grains thereby adhered to the sternal hairs, and subsequently were groomed and packed into the scopae of the hind legs to be carried into the nest. In the process of collecting pollen, bees thereby often manipulated the anthers with their mandibles, most likely to make more pollen available, and perhaps also to feed on pollen. While collecting pollen, they simultaneously collected oil with the front and middle legs as described above. The oil was also transferred to the scopae of the hind legs, where it was transported together with pollen.
The ethogram shows the sequence of collecting behavior by one female and reveals that the first time the female leaves her nest (either in the afternoon or in the morning) to start foraging, she begins with four oil collecting trips (Figure 3 ). The bee used the oil collected during these trips to line a new cell. After finishing the cell lining, she collected oil+pollen as food for the larvae. Provisioning of the cells was conducted in eight collecting trips during the afternoon and six during the morning. During four oil and pollen collecting trips in the afternoon, the bee visited a few Geranium flowers for nectar. Observations of other individuals during nest provisioning confirmed the sequence of behaviors: after excavation of a cell, the bees collected floral oil for the cell lining, and after finishing the cell lining, provided the cell with the larval food. They subsequently laid an egg, probably closed the cell 


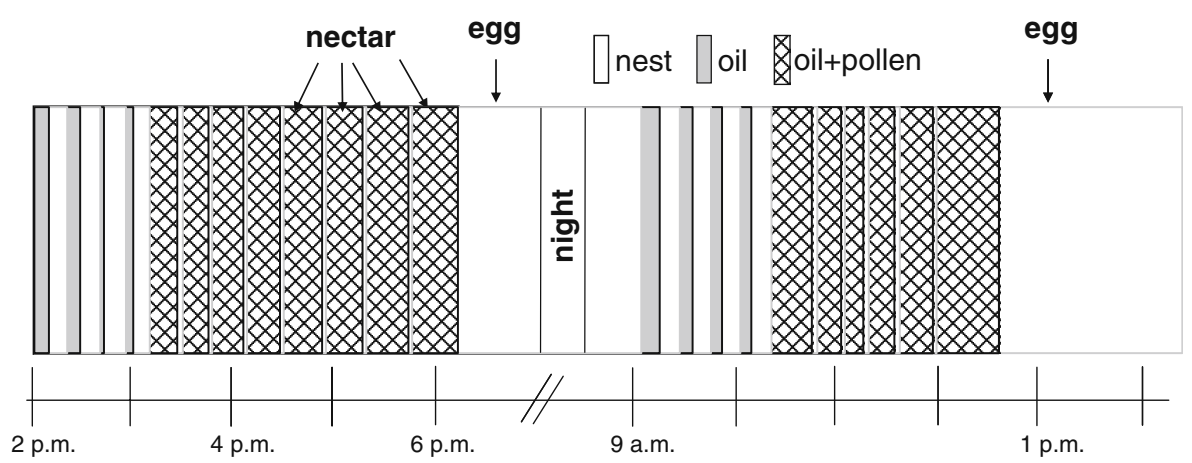

Figure 3. Ethogram showing the behavior of a Macropis fulvipes female during one afternoon and the following morning when provisioning cells. We recorded nest stays, as well as oil and oil+pollen collecting trips. During four oil+pollen collecting trips the bee visited few Geranium flowers each for nectaring and laid an egg in the evening after the last oil+ pollen collection trip of the first day, and another one after the 6th oil+ pollen collecting trip of the second day.

and built a new cell as indicated by burrowing behavior, which we observed in the main tunnel.

The collecting behavior of the female bees in the flight cage was nearly synchronous, and consequently the different kinds of collecting trips (oil versus oil+pollen) were not equally distributed throughout a day (logistic regres- sion, Wald test: $\chi^{2}(1 ; 10)=24.71, P<0.01$; see also Figure 4). There was a diurnal pattern in cell preparation among the bees. Most bees collected oil from 8-9 a.m. and only a few collected oil+pollen at this time $($ median $=0)$. The percentage of bees collecting oil+pollen increased until noon, decreased from noon to

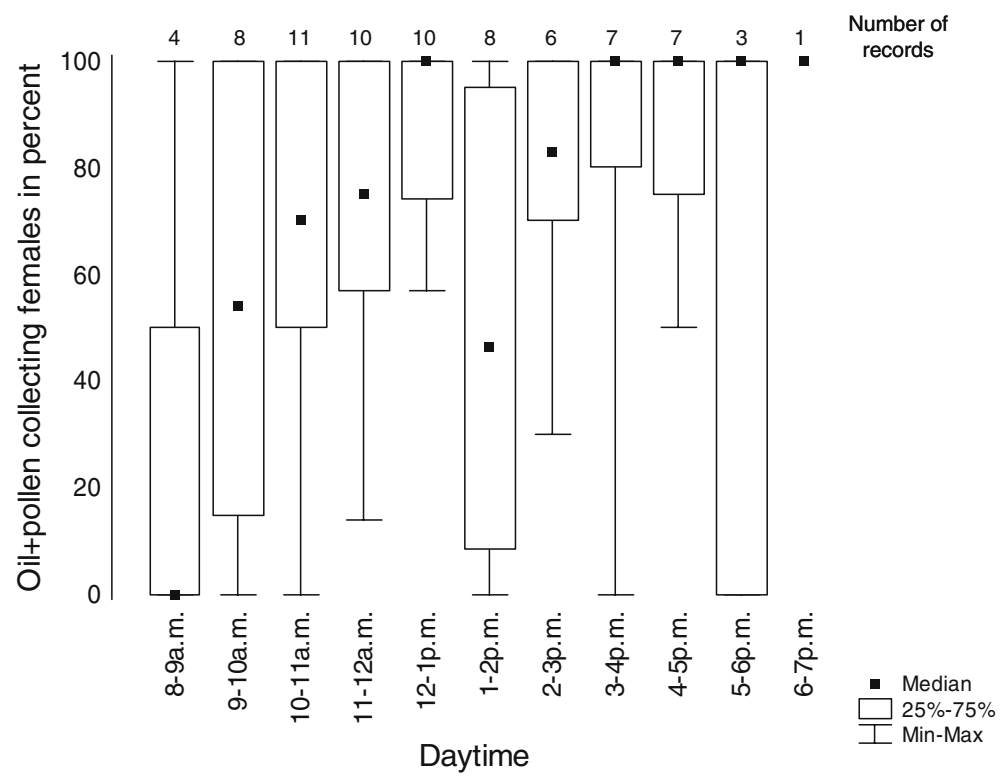

Figure 4. Percentage of females collecting oil+pollen and not only oil in the course of a day. Number of records gives the number of observations in a specific hour (see section 2 for more details). 
early afternoon, and then increased again to $100 \%$ (median) in the afternoon and evening.

\subsection{Quantitative data of collecting behavior}

The duration of a collecting trip and the number of flower visits during one collecting trip differed between the two types of trips (Figure 5a, b). An oil collecting trip lasted 5 min (median), during which 16 flower visits were recorded, whereas an oil + pollen collecting trip lasted 10 min (median) during which 56 flower visits were recorded ( $U$ test oil vs. oil + pollen, collecting trip duration: $Z=-2.87 ; P<0.01, d f=15$; number of flower visits: $Z=-3.09 ; P<0.01, d f=12$ ). When collecting only oil bees visited a flower for twice as long $(11 \mathrm{~s})$ as they did when collecting oil + pollen $(5 \mathrm{~s}$; $U$ test oil vs. oil + pollen, $Z=2.34 ; P=0.02, d f=8$; Figure $5 \mathrm{c})$. The bees stayed longer in the nest after an oil collecting flight $(8 \mathrm{~min})$ compared
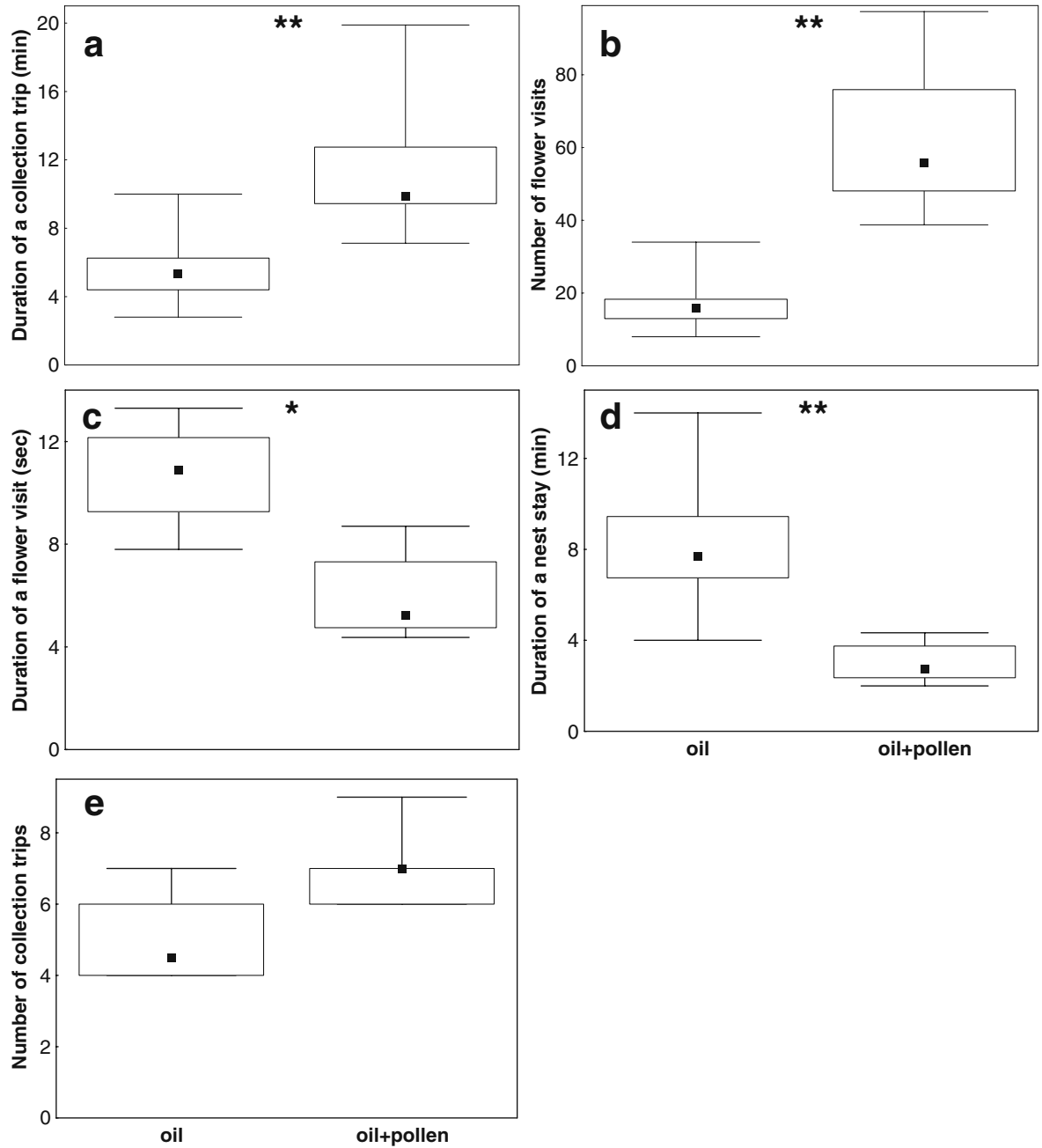

Figure 5. Duration of a collecting trip (a), number of flower visits per collecting trip (b), duration of a flower visit (c), and a nest stay (d), and number of collecting trips to complete one cell (e), depending each on the floral rewards collected (oil vs oil+ pollen). The median, lower and upper quartile, and minimum-maximum are given. $U$ test, $* 0.05>P \geq 0.01 ; * * 0.01>P \geq 0.001$. 
with an oil + pollen collecting flight ( $3 \mathrm{~min} ; U$ test oil vs. oil + pollen, $Z=3.09 ; P<0.01, d f=$ 14; Figure $5 \mathrm{~d}$ ). The oil removal and lining of the cell took more time than the unloading of an oil+pollen packet. In total, females need in the median five oil and seven oil+pollen collecting trips to complete one cell ( $U$ test oil vs. oil+pollen: $Z=-1.88 ; P=0.06, d f=8$; Figure 5e).

Overall, females spent about 1 to $1.5 \mathrm{~h}$ completing the provisions for a larva. The floral products for one larva are collected from 460 flowers (cell lining, 70 flowers and larval provision, 390 flowers; calculated from data presented in Figure 5b, e).

\subsection{Oil+pollen load per bee}

On average, the bees had a fresh body weight of $42 \mathrm{mg}$ (min-max, 33-50 mg), and carried loads of $11 \mathrm{mg}$ (min-max, 7-16 mg), which is approximately a quarter of their body weight (min-max, 18-33\%).

\section{DISCUSSION}

\subsection{Emergence phenology}

In the 4 years of observation, the start of the flight period in both the $M$. fulvipes flight cage population and the free-living population in the EBG was very similar (Schäffler, unpublished data) and generally well timed with the blooming period of the L. punctata host plants. Flight activity periods of oligolectic bees generally correspond to the seasonal blooming period of their host plants (Linsley 1958). The phenology of insects as well as that of plants is regulated by environmental cues (Reeves and Coupland 2000; Mouradov et al. 2002), which might help to maintain synchronization between insects and their host plants especially if they use the same indicators. Photoperiod and temperature strongly influence the rate of diapause development in animals (Danks 2007), and temperature also influences plants' development and leaf-bud breaks in the spring (Wielgolaski 1999). Because
M. fulvipes nests in the ground, temperature rather than photoperiod is more likely to be the trigger for emergence. The initial time of eclosion differed among the four observation years. In the first year, the bees started to emerge in mid-June, whereas emergence in the following years started about 3 weeks earlier, during the second half of May. In plants, onset of flowering correlates with increasing air temperature, especially in spring (in temperate climates), and it was found that the start of flowering could be predicted by using temperature accumulation (heat sum) methods (Galán et al. 2001). By applying these methods to $M$. fulvipes, which is synchronized with the flowering phenology of L. punctata, we found that we could predict the date of emergence of these bees. Macropis bees start to emerge from the nests at a heat sum of $492 \mathrm{~K}$ (from 1st January until emergence of the first individual). This temperature accumulation method, which was originally designed for plants, has not previously been applied to bees (insects), and we therefore cannot compare our data with that for other insects. However, by using other methods (e.g., degree days), it has been shown that developmental temperature thresholds can effectively predict the date of insect emergence (Nietschke et al. 2007) and that the temperature regime during larval/ pupal stages strongly influences emergence phenology of bees (Stephen 1965; Bosch and Kemp 2004). Our results also suggest that the temperature during the 5 weeks before emergence may be especially important for $M$. fulvipes, as there was only a very small difference in the heat sum during this period among the years $(8 \mathrm{~K}$, Table II). Overall, differences in the emergence phenology of Macropis are due to different temperature regimes among the different years.

In three of the four observation years, emergence phenology differed between the sexes and the $M$. fulvipes population was protandrous (Figure 1). Consistent with this finding, Celary (2004), who observed seven aggregated nests of $M$. fulvipes, noticed that males eclosed earlier than females. Protandry is described from numerous other European wild bee species (Westrich 1990) and seems to be a general rule in the life history of solitary bees 
(Stephen et al. 1969). It guarantees the presence of males when females emerge and maximizes the male reproductive success (Linsley 1958; Stephen et al. 1969; Wiklund and Fagerström 1977). Why females and males eclosed simultaneously in 1 year of our observations is so far unclear.

\subsection{Behavior after emergence}

Macropis females visit Lysimachia flowers for three purposes: (a) to feed on pollen, (b) to collect oil for the cell lining, and (c) to collect oil + pollen as provision for the larvae.

a. Pollen feeding has not previously been described for Macropis, and this may be because it is obvious only when bees visit Lysimachia flowers for the first time. However, we cannot exclude that bees also feed on pollen when manipulating the anthers during the process of collecting oil and oil+pollen. Pollen feeding is known from females of several other bee species. Pollen is the principal protein source of female bees (Michener 2007), and is assumed to contribute to oogenesis because bees use proteins from pollen to synthesize egg proteins (Hoover et al. 2006; Schäfer et al. 2006; Minckley et al. 1994; Minckley and Roulston 2006). After feeding on pollen, Macropis females searched for an appropriate nesting site, constructed nests, and started to collect floral rewards (2-3 days after pollen feeding). Interestingly, we also found males of Macropis feeding on Lysimachia pollen. So far, little is known about the importance of pollen feeding in male bees in general, and whether it influences its fitness (e.g., through increasing production of sperm or proteinaceous accessory gland secretions; Colonello and Hartfelder 2005).

b. Our observations demonstrated the existence of oil collecting flights in Macropis. Though Vogel (1986) found females carrying only oil while foraging on Lysimachia, he could not observe the bees during a whole foraging trip in the field and was not sure whether the bees collected pollen subsequent to oil on a single foraging trip or transported the oil without pollen to the nest. Cane (1983a) noticed Macropis nuda females, returning to their nest, carrying liquid on their scopae and assumed that this was used for the cell lining, but he was not sure whether the liquid collected was actually oil. Similar oil collecting flights are, however, known for neotropical oil bees, and females of all these species seem to use oil to line the brood cells (Jesus and Garófalo 2000; Aguiar and Garófalo 2004; Alves-dos-Santos et al. 2002, 2006). In Macropis, Vogel (1976) assumed that floral oil is involved in the cell lining, which was confirmed later on by chemical analyses (Cane et al. 1983a). Cell linings are widespread in oil bees and more generally in other bees. They are hydrophobic, maintain the proper humidity in the cell, and protect the larval provision as well as the immature stages from inundation by water or attack by microorganisms such as fungi (e.g., Stephen et al 1969; Hefetz and Fales 1979; Albans et al. 1980; Cane 1981, Vinson and Frankie 1988; Rozen and Buchmann 1990). Non-oil bees however use resins or Dufour's gland secretions instead of oil to build the cell lining (Albans et al. 1980, Cane 1981). Interestingly, the Dufour's gland in oil bees (Macropis sp. and Tetrapedia sp.) is reduced, and its size is much smaller than in bees using Dufour's secretion for the cell lining (Cane et al. 1983b; Alves-dos-Santos et al. 2006).

Macropis makes 4-5 oil collecting trips to construct the nest cell lining, and this number is similar to that of neotropical oil bees, for example Tetrapedia (Camillo 2004) and Centris (Jesus and Garófalo 2000; Aguiar and Gaglianone 2003; Aguiar and Garófalo 2004). Differences are evident in the time invested in one oil collecting trip among oil bees. M. fulvipes needs $5 \mathrm{~min}$, whereas Tetrapedia and Centris species require about 20 min. A scattered distribution of host plants in the habitat could be responsible 
for the longer time needed in the tropical oil bees, whereas for Macropis oil was available ad libitum close to the nesting sites in the flight cage so that the time may also be increased in free flying Macropis. Additionally, the amount of oil per flower, the scopae absorption capacity of the legs, or the oil collecting behavior (Buchmann 1987) may lead to different times among bees. Beyond that, temporal variations are apparent during the activities of removing the oil and of lining the cells; it takes $8 \mathrm{~min}$ in M. fulvipes (after one trip), much less than in Tetrapedia (mean: 25 min; Alves-dos-Santos et al. 2002; Camillo 2004), but longer than in Centris analis (mean, $3.5 \mathrm{~min}$; Jesus and Garófalo 2000). Additional comparative studies focusing on the behavior of the bees inside the nest are needed to be able to understand the differences among diverse oil bees in the time spent to remove the oil from the scopae and to perform the cell lining.

c. The collection of both oil and pollen during a single foraging trip is known for other Macropis species (Cane et al. 1983a) and for neotropical (Sérsic 2004; Cocucci 1991; Cocucci and Vogel 2001) as well as in South African oil bees (Dötterl, unpublished data). However, Centris and Tapinotaspis species are also known to collect oil and pollen during separate foraging trips (Alves-DosSantos et al. 2002; Aguiar and Gaglianone 2003; Aguiar and Garófalo 2004), and in such cases the bees collect oil for the cell lining (see above), to add it to the pollen mass already present in a partially provisioned cell, or both (Aguiar and Garófalo 2004; Camillo 2004).

Besides collecting oil+pollen in one bout, Macropis even collects oil and pollen simultaneously during a single flower visit. Simultaneous collection of oil and pollen is only known for some neotropical Tapinotaspis bees that collect oil and pollen on Nierembergia (Cocucci 1991), and, for one Chalepogenus species that collects the oil and pollen from Sisyrinchium flowers (Cocucci and Vogel 2001). Other neotropical bees collect oil and pollen sequentially on a single flower (e.g., Tapinotaspis sp. on N. browalloides; Cocucci 1991), whereas the Palaeotropical Ctenoplectra collects pollen, oil, and even nectar sequentially from its cucurbitaceous host plants (Momordica and Thladiantha) during one flower visit (Vogel 1989). But in most cases, oil bees collect either oil or pollen from a specific host plant.

In our investigation, a female required, in the median, seven collecting trips (Figure 5e) to provision a single cell. This finding is similar to the five to eight collection trips suggested for $M$. fulvipes by Vogel (1986) and also similar to the number of trips required by Centris females (Aguiar and Gaglianone 2003; Aguiar and Garófalo 2004). Tetrapedia females need greater than 35 trips to supply their larvae (Camillo 2004), and accordingly it takes much longer to provision a cell (about 40 h, based on Camillo 2004).

Interestingly, $M$. fulvipes females invest less time per flower visit when collecting both oil and pollen, compared with oil alone. Therefore, it appears that Macropis harvests considerably more oil from a flower when restricting its visits to oil collection. Females may collect a smaller amount of oil when collecting both plant products together in order to maintain an optimal oil/pollen ratio for the larval food supply. This oil/pollen ratio may differ from the oil/pollen ratio offered by the flower. A flower seems to have too much oil relative to the pollen (or vice versa: too little pollen relative to the oil). It is unknown how bees determine the optimal proportion of liquid to solids during food provisioning trips (Neff 2008).

Vogel (1986) assumed that Macropis bees collecting both oil and pollen on a foraging trip gather oil actively, and pollen only passively. Our observations, however, demonstrate that pollen is also actively collected. Bees only pressed their abdomen against the anthers when collecting both pollen and oil, while the abdomen is not bent towards the anthers when bees collect only oil. Furthermore, bees scraped the anthers with their mandibles in order to 
harvest more pollen only during trips when both oil and pollen were collected.

\subsection{Number of cells per day}

Under good weather conditions, a M. fulvipes female in the flight cage completed one cell in the afternoon and another cell during the following morning (Figure 2). This individual bee collected oil for the cell lining of one cell in the morning and for another cell in the afternoon. Interestingly, an observation of several additional bees during the day indicated that this pattern generally held for the entire population (Figure 4), suggesting a kind of synchronicity in the behavior of females. Females in the flight cage typically complete two cells per day, one in the morning and one in the afternoon. Under field conditions, however, M. fulvipes seemed to complete only one cell per day (Vogel 1986). The reduction in cell production under field conditions may be constrained by the availability of floral resources or proximity of nectar plants. The tropical and ground nesting oil bee Centris aenea is able to complete two cells per day under field conditions, whereas trap nesting Centris and Tetrapedia need at least 2 days (up to 5 days) for one cell (Jesus and Garófalo 2000; Aguiar and Gaglianone 2003; Aguiar and Garófalo 2004). Most non-oil solitary bee species complete one cell per day, but there are also very productive species, such as Calliopsis persimilis that can complete six cells per day (Danforth 1990). The rate of offspring production depends on the opportunity to gather large amounts of moderate quality pollen or smaller amounts of high quality pollen over a given time frame (Danforth 1990; Kim 1999). One might also expect that oil bees are more productive than non-oil bees, as oil has a higher energy content compared to nectar (Vogel 1974). However, the limiting factor for producing offspring not only depends on food availability but is also related to physiological constraints of egg maturation rates (Bosch 2008). Many different parameters influence the number of cells that a bee completes per day and this makes comparisons of fecundity among oil bees and between oil and non-oil bees difficult to interpret.

\subsection{Number of flowers visited to complete one cell}

We provide the first estimation of the floral visits required to produce an oil bee by counting the number of flower visits by marked individuals of female $M$. fulvipes bees. We found that approximately 70 visits for oil are needed to collect sufficient oil for the nest cell lining and approximately 390 oil+pollen visits are required to fully provision the nest cell, making a total of 460 floral visits necessary to produce one bee. Several thousand flowers were available simultaneously in the flight cage so it would not have been necessary for bees to visit a single flower more than once. However, we cannot exclude the possibility that flowers were visited more than once, and that the number of flowers required to produce one bee is actually somewhat lower than the total floral visits. Floral requirements for some non-oil bees has been estimated to range from 1 to 1,100 (Schlindwein et al. 2005; Müller et al. 2006). The (minimal) number of flowers needed according to such estimations is highly variable and depends not only on the size of the bees but also on the amount of pollen available per flower and other factors such as the protein content of pollen. It is therefore difficult to compare the demand of flowers among bees if they use different host plants.

Habitat loss, fragmentation, and degradation may lead to a shortage in food (and nesting sites) and is assumed to be responsible for the decline of many bee species (Kearns, et al. 1998; Müller et al. 2006). To conserve populations of bees, knowledge about their floral requirements is therefore crucial (Müller et al. 2006). The minimum size of a viable, isolated population of bees is regarded to range from 50 to 500 , in order to maintain sufficient genetic variability for adaptation to changing environmental conditions (Shaffer 1981). Using these values and the data of the flower requirement determined in the present study, we can estimate the number of flowers needed to line the cells and produce enough food for a viable population of $M$. fulvipes at approximately 20,000 for a population of 50 individuals, and 
200,000 for a population of 500 individuals. Because a flowering shoot of $L$. punctata produces ca. 50 flowers, 400-4,000 flowering shoots are needed to support a viable population of $M$. fulvipes. These values represent the lower limits required, as bees may need to produce an excess of cells to maintain a given populations size in order to account for losses (e.g., due to larval mortality). This high floral requirement in $M$. fulvipes explains why large populations of this species are found in Botanical Gardens with large populations of Lysimachia host plants (Westrich 1990).

\subsection{Transport capacity and weight of larval provision}

M. fulvipes females $(8-10 \mathrm{~mm})$ transport on average $25 \%(10.6 \mathrm{mg})$ of their body weight in every oil+pollen trip. One female makes an average of seven trips to provision a single cell (Figure 5e), and the larva therefore gets $74 \mathrm{mg}$ of food (see also, Vogel 1986). So far, no data about the weight of scopal loads or larval provisions are available for other oil bees, but they are available for non-oil bees where weights of pollen loads as well as larval bread varies. Pollen loads of the similarly sized $D i$ eunomia triangulifera (Michener 2007) are $18 \mathrm{mg}$ and the larval bread is $70 \mathrm{mg}$ (Minckley et al. 1994). While the weight of the larval bread is similar in M. fulvipes, the capacity to carry pollen is nearly double that of $D$. triangulifera. Large scopae make it possible for Dasypoda hirtipes $(12-15 \mathrm{~mm})$ to transport about $40 \mathrm{mg}$ (larval supply, $290 \mathrm{mg}$; Westrich 1990) or approximately four times the amount of M. fulvipes. Pollen load weight depends not only on the size of the bee but also on its weight, and the morphology of its scopa. Furthermore, factors such as the type of load carried (dry or wet) as well as pollen texture make comparisons among species difficult (Neff 2008). Overall, Neff (2008) suggests that a female has to collect two to three times its fresh weight to provide a larva. From this perspective, a Macropis provision ball should weigh $80-120 \mathrm{mg}$. The actual weight is slightly lower than the lower limit, which could be because floral lipids have higher energy content compared to nectar, and oil bees collect a smaller amount of oil than non-oil bees nectar (Vogel 1974; Rasmussen 1999).

\subsection{Concluding remarks}

In summary, we studied the bionomics of a solitary, ground nesting bee species in a flight cage. While some of the data observed in our closed system translate to a situation under natural conditions in the field (e.g., sequence of cell construction and provisioning, floral requirement, number of collection trips), others may differ (e.g., duration of a collection trip, and duration to complete one cell). Overall, our study gives new insights into the behavior of an oil bee, and generally shows that observations of solitary bees in a closed system are useful to learn more about their bionomics.

\section{ACKNOWLEDGMENTS}

We are grateful to Gregor Aas for providing the greenhouse for the flight cage, the gardeners of the Ecological Botanical Garden (EBG) of the University of Bayreuth for making Lysimachia plants available, Bernhard Liedl for providing the flexible endoscope, and to Kathrin Milchreit for providing a photograph. Temperature data from the EBG were kindly provided by the Department of Micrometeorology, University of Bayreuth. Thomas Foken helped to calculate temperature sums. Andrea Cocucci and Kim Steiner as well as two anonymous referees gave valuable comments on earlier versions of the manuscript.

Une journée dans la vie d'une abeille récolteuse d'huile: phénologie, comportement de nidification et d'approvisionnement.

Macropis fulvipes / somme des températures / abeille solitaire / Lysimachia / plante hôte / comportement de ponte / comportement d'approvisionnement

Zusammenfassung - Ein Tag im Leben einer Ölbiene: Phänologie, Nestbau- und Verproviantierungsverhalten. Bienen sind die wichtigsten Bestäuber vieler Kultur- sowie Wildpflanzen (Klein et al. 2007; Michener 2007). Der Verlust von Lebensräu- 
men bedingt durch die Veränderung von Landschaften führte $\mathrm{zu}$ einer Abnahme der Bienen in den letzten Jahrzehnten (Kearns and Inouye 1997; Murray et al. 2009). Um Bienen langfristig schützen zu können, ist es wichtig, deren Biologie und besonders deren Habitatansprüche (z. B. Anzahl benötigter Blüten, Niststandorte) zu kennen. Die vorliegende Arbeit befasst sich mit der Bionomie der im Boden nistenden und solitär lebenden Schenkelbiene Macropis fulvipes, die wir vier Jahre lang in einem Flugkäfig untersuchten. M. fulvipes ist auf das Blütenöl und den Pollen des Gilbweiderichs (Lysimachia spp.) spezialisiert. Das Blütenöl wird benutzt, um einzelne Brutzellen auszukleiden und zusammen mit Pollen dient es als Larvenfutter. Im ersten Beobachtungsjahr schlüpften die Bienen zwischen Mitte und Ende Juni, und damit ungefähr einen Monat später als in den darauffolgenden Jahren (Tab. I), wobei die Schlüpfzeit immer mit der Blütezeit der Wirtspflanze korrelierte. Möglicherweise waren Temperaturunterschiede zwischen den Jahren für diese Unterschiede in der Phänologie verantwortlich (Galán et al. 2001). In drei der vier Jahre erschienen die Männchen früher als die Weibchen. Bis auf ein Jahr, in dem mehr Weibchen als Männchen schlüpften, war das Geschlechterverhältnis ausgeglichen (Abb. 1; Tab. I). Nach dem Schlüpfen besuchten männliche sowie weibliche Bienen Blüten von L. punctata, um Pollen $\mathrm{zu}$ fressen (Abb. 2a, b). Proteine sind bei weiblichen Bienen für das Reifen der Eier wichtig (z.B. Hoover et al. 2006) und auch bei Männchen könnten sie einen Einfluss auf die Fertilität haben (Colonello and Hartfelder 2005). Die Weibchen begannen zwei bis drei Tage nach dem Fressen von Pollen und dem Graben eines Nestes, Blütenprodukte zu sammeln. Zuerst wurde Öl von L. punctata Blüten gesammelt (hauptsächlich morgens und am frühen Nachmittag, Abb. 3 and 4), um damit die Brutzellen auszukleiden. Danach besuchten sie die Blüten, um gleichzeitig Öl und Pollen als Larvenfutter zu sammeln. Einzelne ÖlSammelflüge dauerten 5 Minuten, für einen Öl+PollenSammelflug benötigten die Weibchen die doppelte Zeit (Abb. 5a). Während eines Öl-Sammelflugs besuchten sie 16 Blüten. Vier bis fünf solcher Flüge waren für die Auskleidung einer Brutzelle nötig. Während eines Öl+ Pollen-Sammelfluges besuchten die Weibchen 66 Blüten. Sieben solcher Sammelflüge waren nötig, um eine Brutzelle zu verproviantieren. Das Sammeln von Öl dauerte elf Sekunden pro Blütenbesuch, das Sammeln von Öl+Pollen nur die Hälfte dieser Zeit. Daraus lässt sich folgern, dass die Blüten verhältnismäBig viel Öl im Vergleich zu Pollen produzieren und das Öl zu Pollen Verhältnis des Larvenfutters nicht dem Öl zu Pollen Verhältnis in einer Blüte gleicht. Nach einem Öl-Sammelflug verblieben die Weibchen für sieben Minuten im Nest, nach einem Ö1+Pollen-Sammelflug drei Minuten. Die Bienen benötigten $1 \mathrm{~h}$, um Öl zu sammeln und die Zelle auszukleiden, 1,5 h, um Öl+ Pollen zu sammeln und die Brutzelle zu verproviantieren. Sie besuchten ca. 460 Blüten, um eine Zelle fertig $\mathrm{zu}$ stellen. Bei guten Witterungsbedingungen stellten die Bienen zwei Zellen pro Tag fertig. Zum einen gibt unsere Studie einen neuen Einblick in das Verhalten einer Ölbiene und zum anderen zeigt sie, dass Beobachtungen von solitären Bienen in einem Flugkäfig hilfreich sind, um mehr über deren Lebensweise und deren Ansprüche zu erfahren (Goubara and Takasaki 2003; Schindler 2004).

\section{Macropis fulvipes / Ölbiene / Temperatursumme / Solitärbiene / Bedarf an Lysimachia Wirtspflanzen / Nestbau- und Verproviantierungsverhalten}

\section{REFERENCES}

Aguiar, C.M.L., Gaglianone, M.C. (2003) Nesting biology of Centris (Centris aenea) Lepeletier (Hymenoptera, Apidae, Centridini). Rev. Bras. Zool. 20, 601-606

Aguiar, C.M.L., Garófalo, C.A. (2004) Nesting biology of Centris (Hemisiella) tarsata Smith (Hymenoptera, Apidae, Centridini). Rev. Bras. Zool. 21, 477486

Albans, K.R., Aplin, R.T., Brehcist, J., Moore, J.F., O'Toole, C. (1980) Dufour's gland and its role in secretion of nest cell lining in bees of the genus Colletes (Hymenoptera: Colletidae). J. Chem. Ecol. 6, 549-564

Alves-Dos-Santos, I., Melo, G.A.R., Rozen, J.G. (2002) Biology and immature stages of the bee tribe Tetrapediini (Hymenoptera: Apidae). Am. Mus. Novit. 3377, 1-45

Alves-Dos-Santos, I., Naxara, S.R.C., Patrício, E.F.L. R.A. (2006) Notes on the morphology of Tetrapedia diversipes KLUG 1810 (Tetrapediini, Apidae), an oil collecting bee. Braz. J. Morphol. Sci. 23, 425-430

Batra, S.W.T. (1995) Bees and pollination in our changing environment. Apidologie 26, 361-370

Biesmeijer, J.C., Roberts, S.P.M., Reemer, M., Ohlemuller, R., Edwards, M., Peeters, T., Schaffers, A.P., Potts, S. G., Kleukers, R., Thomas, C.D., Settele, J., Kunin, W. E. (2006) Parallel declines in pollinators and insectpollinated plants in Britain and the Netherlands. Science 313, 351-354 
Bosch, J. (2008) Production of undersized offspring in a solitary bee. Anim. Behav. 75, 809-816

Bosch, J., Kemp, W.P. (2004) Effect of pre-wintering and wintering temperature regimes on weight loss, survival, and emergence time in the mason bee Osmia cornuta (Hymenoptera: Megachilidae). Apidologie 35, 469-479

Buchmann, S.L. (1987) The ecology of oil flowers and their bees. Annu. Rev. Ecol. Syst. 18, 343-369

Camillo, E. (2004) Nesting biology of four Tetrapedia species in trap-nests (Hymenoptera: Apidae: Tetrapediini). Rev. Biol. Trop. 53, 175-186

Cane, J.H. (1981) Dufour's gland secretion in the cell linings of bees (Hymenoptera: Apoidea). J. Chem. Ecol. 7, 403-410

Cane, J.H., Eickwort, G.C., Wesley, F.R., Spielholz, J. (1983a) Foraging, grooming, and mating behaviors of Macropis nuda (Hymenoptera: Melittidae) and use of Lysimachia ciliata (Primulaceae) oils in larval provisions and cell lining. Am. Midl. Nat. 110, 257264

Cane, J.H., Gerdin, S., Wife, G. (1983b) Mandibular gland secretions of solitary bees (Hymenoptera, Apoidea) - potential for nest cell disinfection. J. Kans. Entomol. Soc. 56, 199-204

Celary, W. (2004) A comparative study on the biology of Macropis fulvipes (Fabricius, 1804) and Macropis europaea Warncke 1973 (Hymenoptera: Apoidea: Melittidae). Folia. Biol. Krak. 52, 81-85

Cocucci, A.A. (1991) Pollination biology of Nierembergia (Solanaceae). P1. Syst. Evol. 174, 17-35

Cocucci, A.A., Vogel, S. (2001) Oil-producing flowers of Sisyrinchium species (Iridaceae) and their pollinators in southern South America. Flora 196, 26-46

Colonello, N.A., Hartfelder, K. (2005) She's my girlmale accessory gland products and their function in the reproductive biology of social bees. Apidologie 36, 231-244

Cox-Foster, D.L., Conlan, S., Holmes, E.C., Palacios, G., Evans, J.D., Moran, N.A., Quan, P.L., Briese, T., Hornig, M., Geiser, D.M., Martinson, V., van Engelsdorp, D., Kalkstein, A.L., Drysdale, A., Hui, J., Zhai, J., Cui, L., Hutchison, S.K., Simons, J.F., Egholm, M., Pettis, J.S., Lipkin, W.I. (2007) A metagenomic survey of microbes in honey bee colony collapse disorder. Science 318, 283-287

Danforth, B.N. (1990) Provisioning behavior and the estimation of investment ratios in a solitary bee, Calliopsis (Hypomacrotera) persimilis (Cockerell) (Hymenoptera: Andrenidae). Behav. Ecol. Sociobiol. 27, 159-168

Danks, H.V. (2007) The elements of seasonal adaptations in insects. Can. Entomol. 139, 1-44

Dötterl, S., Schäffler, I. (2007) Flower scent of floral oilproducing Lysimachia punctata as attractant for the oil bee Macropis fulvipes. J. Chem. Ecol. 33, 441-445
Galán, C., Cariñanos, P., García-Mozo, H., Alcázar, P., Domínguez-Vilches, E. (2001) Model for forecasting Olea europaea L. airborne pollen in SouthWest Andalusia, Spain. Int. J. Biometeorol 45, 5963

Goubara, M., Takasaki, T. (2003) Flower visitors of lettuce under field and enclosure conditions. Appl. Entomol. Zool. 38, 571-581

Hefetz, A., Fales, H.M. (1979) Natural polyesters: Dufour's gland macrocyclic lactones form brood cell laminesters in Colletes bees. Science 204, 415-417

Hoover, S.E.R., Higo, H.A., Winston, M.L. (2006) Worker honey bee ovary development: seasonal variation and the influence of larval and adult nutrition. J Comp Physiol B 176, 55-63

Jesus, B.M.V., Garófalo, C.A. (2000) Nesting behaviour of Centris (Heterocentris) analis (Fabricius) in southeastern Brazil (Hymenoptera, Apidae, Centridini). Apidologie 31, 503-515

Kearns, C.A., Inouye, D.W. (1997) Pollinators, flowering plants, and conservation biology. Bioscience 47, 297-307

Kearns, C.A., Inouye, D.W., Waser, N.M. (1998) Endangered mutualisms: the conservation of plant-pollinator interactions. Ann. Rev. Ecolog. Syst. 29, 83-112

Kevan, P.G. (1999) Pollinators as bioindicators of the state of the environment: species, activity and diversity. Agric. Ecosyst. Environ. 74, 373-393

Kevan, P.G., Phillips, T.P. (2001) The economic impacts of pollinator declines: an approach to assessing the consequences. Conserv Ecol 5, 8

Klein, A.M., Vaissière, B.E., Cane, J.H., SteffanDewenter, I., Cunningham, S.A., Kremen, C., Tscharntke, T. (2007) Importance of pollinators in changing landscapes of world crops. Proc. Roy. Soc. B. Biol. Sci. 274, 303-313

Kim, J.Y. (1999) Influence of resource level on maternal investment in a leaf-cutter bee (Hymenoptera: Megachilidae). Behav. Ecol. 10, 552-556

Laaidi, M. (2001) Forecasting the start of the pollen season of Poaceae: evaluation of some methods based on meteorological factors. Int. J. Biometeorol 45, 1-7

Linsley, E.G. (1958) The ecology of solitary bees. Hilgardia 27, 543-599

Malyshev, S.I. (1929) The nesting habits of Macropis Pz. (Hym. Apoidea). Eos. 5, 97-109

Michener, C.D. (2007) The bees of the world. The John Hopkins University Press, Baltimore

Michez, D., Patiny, S. (2005) World revision of the oil collecting bee genus Macropis Panzer 1809 (Hymenoptera: Apoidea: Melittidae) with a description of a new speciesfrom Laos. Ann. Soc. Entomol. Fr. 41, $15-28$

Minckley, R.L., Wcislo, W.T., Yanega, D.A., Buchmann, S.L. (1994) Behavior and phenology of a specialist 
bee (Dieunomia) and sunflower (Helianthus) pollen availability. Ecology 75, 1406-1419

Minckley, R.L., Roulston, T.H. (2006) Incidental mutualisms and pollen specialization among bees. In: Waser, N.M., Ollerton, J. (eds.) Specialization and generalization in plant-pollinator interactions, pp. 69-98. The University of Chicago Press, Chicago

Mouradov, A., Cremer, F., Coupland, G. (2002) Control of flowering time: interacting pathways as a basis for diversity. Plant Cell. 14, 111-130

Müller, A., Diener, S., Schnyder, S., Stutz, K., Sedivy, C., Dorn, S. (2006) Quantitative pollen requirements of solitary bees: implications for bee conservation and the evolution of bee-flower relationships. Biol. Conserv. 130, 604-615

Murray, T.E., Kuhlmann, M., Potts, S.G. (2009) Conservation ecology of bees: populations, species and communities. Apidologie 40, 211-236

Neff, J.L. (2008) Components of nest provisioning behavior in solitary bees (Hymenoptera: Apoidea). Apidologie 39, 30-45

Neff, J.L., Simpson, B.B. (2005) Rewards in flowers. Other rewards: oils, resins, and gums. In: Dafni, A., Kevan, P.G., Husband, B.C. (eds.) Practical Pollination Biology, pp. 314-328. Enviroquest, Ltd., Cambridge

Nietschke, B.S., Magarey, R.D., Borchert, D.M., Calvin, D.D., Jones, E. (2007) A developmental database to support insect phenology models. Crop. Prot. 26, 1444-1448

Rasmussen, C. (1999) Coevolution of the oil beeCalceolaria system in the Andes of Peru. M.Sc. thesis, University of Aarhus, Denmark. Available at: http://science.melipona.org/PDF/MSc\%20thesis\% 20\%281999\%29.pdf

Renner, S.S., Schäfer, H. (2010) The evolution and loss of oil-offering flowers: new insights from dated phylogenies for angiosperms and bees. Philos. T. Roy. Soc. B 365, 423-435

Reeves, P.H., Coupland, G. (2000) Response of plant development to environment: control of flowering by daylength and temperature. Curr. Opin. Plant Biol. 3, 37-42

Rozen, J.G., Buchmann, S.L. (1990) Nesting biology and immature stages of bees Centris caesalpinae, $C$. pallida, and the cleptoparasite Ericrocis lata (Hymenoptera: Apoidea: Anthophoridae). Am. Mus. Novit. 2985, 1-30

Schäfer, M.O., Dietemann, V., Pirk, C.W.W., Neumann, P., Crewe, R.M., Hepburn, H.R., Tautz, J., Crailsheim, K. (2006) Individual versus social pathway to honeybee worker reproduction (Apis mellifera): pollen or jelly as protein source for oogenesis? J. Comp. Physiol. A 192, 761-768

Schindler, M. (2004) Biologie kleptoparasitischer Bienen und ihrer Wirte (Hymenoptera, Apiformes). Labor- und Freilanduntersuchungen an Arten der Gattungen Nomada und Andrena, Dissertation, Rheinische Friedrich-Wilhelms-Universität, Bonn

Schlindwein, C., Wittmann, D., Martins, C.F., Hamm, A., Siqueira, J.A., Schiffler, D., Machado, I.C. (2005) Pollination of Campanula rapunculus $\mathrm{L}$. (Campanulaceae): how much pollen flows into pollination and into reproduction of oligolectic pollinators? Plant. Syst. Evol. 250, 147-156

Sérsic, A.N. (2004) Pollination biology in the genus Calceolaria (Calceolariaceae), Stapfia 82, 1-121

Shaffer, M.L. (1981) Minimum population sizes for species conservation. Bioscience 31, 131-134

Simpson, B.B., Neff, J.L. (1981) Floral rewards: alternatives to pollen and nectar. Ann Mo Bot Gard 68, 301-22

StatSoft, Inc. (2004) STATISTICA (data analysis software system), version 7. Available at: www.statsoft.com

Steffan-Dewenter, I., Potts, S.G., Packer, L. (2005) Pollinator diversity and crop pollination services are at risk. Trends. Ecol. Evol. 20, 651-652

Stephen, W.P. (1965) Temperature effects on the development and multiple generations in the alkali bee, Nomia melanderi Cockerel. Entomol. Exp. Appl. 8, 228-240

Stephen, W.P., Bohart, G.E., Torchio, P.F. (1969) The biology and external morphology of bees; with a synopsis of the genera of northwestern America, Corvallis. Agricultural Experiment Station, Oregon State University, Oregon

Vinson, S.B., Frankie, G.W. (1988) A comparative study of the ground nests of Centris flavifrons and Centris aethiocesta (Hymenoptera: Anthophoridae). Entomol. Exp. Appl. 49, 181-187

Vogel, S. (1974) Ölblumen und ölsammelnde Bienen, Trop. u. subtrop. Pflanzenwelt 7, 1-267

Vogel, S. (1976) Lysimachia: Ölblumen der Holarktis. Naturwissenschaften 63, 44

Vogel, S. (1986) Ölblumen und ölsammelnde Bienen, Zweite Folge: Lysimachia und Macropis Trop. u. subtrop. Pflanzenwelt 54, 1-168

Vogel, S. (1989) Fettes Öl als Lockmittel- Erforschung der ölbietenden Blumen und ihrer Bestäuber, in: Akademie der Wissenschaften und der Literatur Mainz, Jubiläumsband, Franz Steiner Verlag, Stuttgart. pp 113-130

Westrich, P. (1990) Die Wildbienen BadenWürttembergs, 2 Aufl. Ulmer Verlag, Band II

Wielgolaski, F.E. (1999) Starting dates and basic temperatures in phenological observations of plants. Int. J. Biometeorol. 42, 158-168

Wiklund, C., Fagerström, T. (1977) Why do males emerge before females - hypothesis to explain incidence of protandry in butterflies. Oecologia 31, 153-158 